\section{Lavkarbokosthold - bekreftet helseeffekt?}

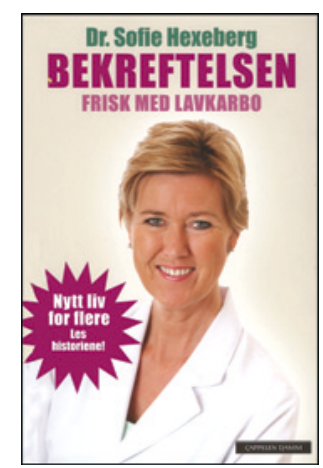

\author{
Sofie Hexeberg \\ Bekreftelsen \\ Frisk med lavkarbo. 238 s, tab. Oslo: Cappelen \\ Damm, 2012. Pris NOK 349 \\ ISBN 978-82-02-36755-8
}

Lege Sofie Hexeberg ga i mars 2010 ut sin første bok Frisk med lavkarbo - nytt liv med riktig mat. Bok nr. to, Bekreftelsen, består for det meste av gladmeldinger forfatteren har mottatt i kjølvannet av den første utgivelsen - en mengde pasienthistorier som, ifølge forfatteren, viser bredden av lavkarbokostens helseeffekter.

I tillegg til brev og mailer fra personer som har lest den første boken, beskriver forfatteren en del pasienthistorier fra Dr. Hexebergs klinikk. Klinikken ble etablert i august 2010 og drives av forfatteren og hennes mann, lege Erik Hexeberg.

I den første delen kan vi lese vitnesbyrd (fra perioden 19. mars 2010 til 30. juli 2010) om lavkarbokostens fortreffelighet i forhold til vektproblemer, søvnapné, snorking, høyt blodtrykk, nedstemthet, utslett, uren hud, premenstruelt stress, tretthet, hukommelsessvikt, konsentrasjonsvansker, hårtap, tannkjøttbetennelse, kalde hender og føtter, generelle smerter, hetetokter, dårlig fordøyelse, kronisk utmattelsessyndrom (ME), fibromyalgi, ustabilt blodsukker, energitap, tinnitus, after, psoriasis og polycystisk ovariesyndrom. Inkludert er også brev fra et par medisinstudenter og kolleger. Historiene er godt skrevet og enkelt formulert, og det er lett å føle på takknemligheten i disse historiene.

Videre får vi ta del i positive tilbakemeldinger på Facebooksiden Frisk med lavkarbo. Her presenteres gladmeldinger i forhold til psoriasisleddgikt, soleksem, matintoleranser, vektproblemer, bjørkepollenallergi, allergier, migrene, Crohns sykdom, lavt stoffskifte og kroniske smerter.

Forfatteren er tydelig på at hun ikke fullt ut kan forklare hvorfor folk føler seg friskere av lavkarbokost, men hun kommer med mulige forklaringer som at vi er genetisk tilpasset til å spise kjøtt, fisk, skalldyr, fugl, nøtter, grønnsaker, bær og litt frukt, og at vi blir syke av å spise fuglemat, som korn i prinsippet er.

Etter enda noen pasienteksempler beskriver forfatteren flere lidelser med påfølgende pasienteksempler og mulige forklaringsmodeller. Vi lærer om migrene og hodepine, epilepsi, fedme, høyt blodtrykk, type 1- og 2-diabetes, polycystisk ovariesyndrom og graviditet, multippel sklerose, Bekhterevs sykdom, psoriasis, psoriasisartritt, leddgikt, matintoleranse og irritabel tarm-syndrom, cøliaki, Crohns sykdom og ulcerøs kolitt.

Forklaringsmodellene forfatteren bruker, er at ustabilt blodsukker fører til sult, hyperinsulinemi fører til fettlagring, og omega6-fett fra korn fører til produksjon av betennelsesfremmende eikosanoider.

Videre beskriver hun hvordan vi etter fire uker på lavkarbokost vil kunne trene med mer energi. Dette etterfølges av et par kasuistikker.

Noen pasienter går ikke ned i vekt på lavkarbokost. Vi lærer at kronisk syke bruker næringsstoffene i lavkarbokosten til å reparere seg selv: «Dersom du har behov for å bekjempe betennelse, bygge opp muskulatur, reparere slimhinner og lignende, er det logisk at kroppen din ikke gir fra seg energi uten videre. En kronisk syk kropp er dessuten under stress, noe som også hemmer vektreduksjonen. Det kan gå flere måneder før kronisk syke begynner å gi fra seg av fettlagrene.»

I tillegg kan årsaken til manglende vektreduksjon skyldes småspising, for store porsjoner, for mye av sunne nøtter, for lite søvn, mat for sent om kvelden eller for mye karbohydrater.

Vi får en enkel innføring i mengde karbohydrater i lavkarbokost, øvre grense i low calorie high fat-kost (LCHF), normal mengde karbohydrater i LCHF-kost og karbohydrater i strikt LCHF-kost. Dette var nyttig informasjon. Litt skremmende er likevel uttalelsen om at kornfiber vil skrape opp den beskyttende tarmslimhinnen slik at underliggende vev i tarmveggen kan skades.

Redselen for kolesterol og fett er viet et kapittel, der forfatteren, sammen med sin mann, gir en innføring i begrepene triglyserider, totalkolesterol, very low, intermediate, low og high density lipoprotein. Hun viser til sine egne blodprøvesvar etter flere år på lavkarbokost, og de er fine.

Her refereres til vitenskapelige artikler når sammenhengen mellom inntak av mettet fett og hjerte- og karsykdommer beskrives, og konklusjonen er at inntak av mettet fett i seg selv ikke er årsak til disse sykdommene.

Vegetarianere, gravide, ammende og barn kan alle bruke lavkarbokost, ifølge forfatteren.

Referanser som er brukt, er artikler om fett og hjerteog karsydommer, blogger, bøker og nettadresser som www.carbohydratescankill.com www.annikadahlqvist.se, www.lenabeatrice.net og www.espenrostrup.com.

Boken vil, med confirmation bias i tankene, utvilsomt treffe blink hos forfatterens tilhengere, mens den vil forsterke skepsisen hos oss andre.

\section{Mette Helvik Morken}

Institutt for indremedisin

Universitetet i Bergen 